\title{
ENGEVISTA
}

Página da revista: http://www.uff.br/engevista/seer/

\section{Influence of different inductors and operating conditions in the production of lipase from Aspergillus niger using cassava peel: a short study}

\author{
Aniela Pinto Kempka ${ }^{1}$ \\ Adriane Mocelin ${ }^{2}$ \\ Cindiamara Cazagranda ${ }^{3}$ \\ Fernanda de Campos Goulart ${ }^{4}$ \\ Vanessa Daiane Heinzen ${ }^{5}$ \\ Rosa Cristina Prestes ${ }^{6}$
}

\begin{abstract}
The lipase production using microorganisms is very advantageous, especially because of their high productivity and the possibility of use of agro-industrial wastes as substrate. In the present study, there was the possibility that supplementation of cassava peel with different inductors (soybean oil, maize oil, frying oil, swine fat, glucose and yeast extract). Subsequently it was sought to maximize the production of the enzyme by varying the concentration of inductor and the fermentation temperature using the technique of experimental design and response surface. In the first step of the study, were obtained as better inductor swine fat, compared to vegetable oils and other inductors. The swine fat used as inductor resulted a lipase activity of $70.82 \pm 6.07 \mathrm{U} / \mathrm{g}$, this value being statistically equal ( $>0.05$ ) to values of lipase activity obtained from the cassava peel supplemented with soybean oil $(2.5 \% \mathrm{w} / \mathrm{w})+$ glucose $(1 \% \mathrm{w} / \mathrm{w})$ and maize oil $(2.5 \% \mathrm{w} / \mathrm{w})+$ glucose $(1 \% \mathrm{w} / \mathrm{w})$. In optimizing of temperature and concentration of inductor, was defined, from the statistical treatments, $36^{\circ} \mathrm{C}$ as the optimum temperature for fermentation and $1 \%(\mathrm{w} / \mathrm{w})$ as the concentration of inductor (swine fat), with maximum activity lipase obtained from $72.26 \pm 2.56 \mathrm{U} / \mathrm{g}$.
\end{abstract}

Keywords: Cassava peel, inductors, solid state fermentation, operational variables.

\footnotetext{
${ }^{1}$ UDESC - Universidade do Estado de Santa Catarina

2 UDESC - Universidade do Estado de Santa Catarina

${ }^{3}$ UDESC - Universidade do Estado de Santa Catarina

${ }^{4}$ UDESC - Universidade do Estado de Santa Catarina

${ }^{5}$ UDESC - Universidade do Estado de Santa Catarina

${ }^{6}$ UFSM - Universidade Federal de Santa Maria
}

ENGEVISTA, V. 19, n.1 , p. 9-18, Janeiro 2017. 


\section{Introduction}

Lipases (triacylglycerol acylhydrolases, EC 3.1.1.3) are important industrial enzymes due to their versatile applications (Salihu et al., 2012). They need to be robust and versatile with respect to the range of substrates they can act on, but at the same time they should have a high specificity for the reactions they catalyze (Gupta et al., 2004).

Lipases catalyze the hydrolysis of acyl glycerol to fatty acids, di-acyl glycerol, mono-acyl glycerol and glycerol. Under certain conditions, they also catalyze the synthesis of esters by transesterification, thioesterification and aminolysis (Mahadik et al. 2002).

Microbial lipases have considerable industrial potential as a catalyst for hydrolysis, synthesis and trans-esterification of tri-acyglycerol owing to advantages such as high levels of production and diversity of stero-specific properties (Tan et al., 2003). The unique properties of lipase catalyzed reactions such as chemoselectivity, regioselectivity, stereoselectivity, nonrequirement of cofactors and stability in organic solvents make microbial lipase a versatile biocatalyst in many industrial applications such as foods, cosmetics, detergents, biosensors, pharmaceuticals, and recently in the field of bioenergy especially in biodiesel production (Salihu et al., 2011).

The natural substrates of lipases are practically insoluble in water, so the reaction is catalyzed at the water-lipid interface and does not follow the classic Michaelis-Menten kinetics (Guncheva and Zhiryakova, 2011).

In the last two decades, the Solid-State Fermentation has attracted increasing attention for the production of enzymes, metabolites, etc., due to several biotechnological advantages such as higher fermentation productivity, higher end-product concentration, higher product stability and lower catabolic repression (Li and Zong 2010).

The Solid-State Fermentation (SSF) is defined as the fermentation on moist solid substrate in the absence or near absence of free water, thus being close to the natural environment to which microorganisms are adapted (Li and Zong 2010; Santis-Navarro et al., 2011), mainly filamentous fungi as Aspergillus niger.

Filamentous fungi are recognized as the best lipase producers and are currently the preferred sources since they produce extracellular lipases, facilitating the extraction from fermentation media (Contesini et al., 2010).

Several factors have been reported to affect the extracellular lipase production such as $\mathrm{pH}$, temperature, aeration and medium composition (Salihu et al., 2011). Many studies have been undertaken to define the optimal culture and nutritional requirements for lipase production. These requirements are influenced by the type and concentration of the carbon and nitrogen sources, culture $\mathrm{pH}$ and growth temperature (Contesini et al., 2010). 
Therefore, the improvement in productivity of lipases can be achieved through manipulation of nutritional as well as physical parameters (Salihu et al., 2011). Lipidic carbon sources generally seem to be essential to obtain a high lipase yield, although a few authors observed that the presence of fats and oils was not statistically significant for enzyme production (Contesini et al., 2010).

Therefore, the objective of this study was to produce lipase from Aspergillus niger in SSF using cassava peel added with different inducers. Subsequently, verify the operating conditions (temperature and concentration of inducer) for maximizing the production of the enzyme.

\section{Material and methods}

The experiments for the production of lipase were conducted at the Laboratory of Bioprocess and Laboratory of Microbiology, Department of Food Engineering and Chemical Engineering (DEAQ), State University of Santa Catarina (UDESC).

\subsection{Microbial culture and inoculum preparation}

The propagation of spores of Aspergillus niger prior to fermentation was carried out for 7 days at $27.5^{\circ} \mathrm{C}$ in a medium constituted by potato dextrose agar (PDA) $3.9 \%(\mathrm{w} / \mathrm{v}$ ) and distilled water. Medium for inoculum production consisted of (w/v): $2 \%$ starch, $1 \%$ olive oil, $0.1 \%$ yeast extract, $0.025 \% \mathrm{MgSO}_{4} .7 \mathrm{H}_{2} \mathrm{O}, 0.05 \% \mathrm{KH}_{2} \mathrm{PO}_{4}, 0.5 \% \mathrm{CaCO} 3$ and $1.5 \%$ agar. This medium was inoculated with a spore suspension and incubated at $27^{\circ} \mathrm{C}$ for 7 days. The spores were collected adding $10 \mathrm{~mL}$ of a sterile $0.1 \%$ Tween 80 aqueous solution and glass beads to the fermented agar medium and kept at $4^{\circ} \mathrm{C}$ until use (Kempka et al., 2008).

\subsection{Physicochemical characterization of cassava peel}

The physicochemical characterizations of cassava peel, such as $\mathrm{pH}$, moisture, ash and starch were analyzed. For the determination of $\mathrm{pH}, 5 \mathrm{~g}$ of peel homogenized in $5 \mathrm{~mL}$ distilled water were used and preceded with the reading digital potentiometer (Quimis).

For the moisture determination, the authors used the gravimetric method. For the determination of ash, incineration was used in a muffle at $550^{\circ} \mathrm{C}$ and for determination of starch, the authors used the method of acid digestion and determination of sugars reducers (Adolfo Lutz Institute, 2008).

\subsection{Preparation of the medium of solid state fermentation}

Was used as substrate (cassava peel) previously comminuted and dried in an oven temperature of $105^{\circ} \mathrm{C}$ for 24 hours and subsequently frozen for maintaining their physicochemical 
characteristics. The experiments for lipase production were carried out aseptically in conical reactors covered with hydrophobic fabric. Aqueous solution containing the inductors was added to the substrate and the resulting medium was then sterilized at $121^{\circ} \mathrm{C}$ for 20 minutes.

The sterile medium was then inoculated with 108 spores/g dry substrate using spore suspension previously prepared. Cultivation was carried out in an incubator BOD during 60 hours according to Gerber et al. (2013). The moisture of the medium was set at 55\% in accordance with Kempka et al., (2008).

\subsection{Study of inductors to the production of lipase}

The inductors used in this study were soybean oil, maize oil, frying oil (collected in a restaurant after being reused), swine fat (oils and fats was considered a supplementary carbon source since their composition is mainly constituted by lipids), glucose and yeast extract. Table 1 shows the experiments with inductors used and the concentration of each inductor.

\subsection{Optimization of lipase production}

After defining the inductor, held a factorial design with 2 factors and 4 axial points (22) out to evaluate the effect of incubation temperature $\left(22.7-38.2^{\circ} \mathrm{C}\right)$ and inductor concentration $(0.4-4.6 \%)$ on lipase production. The range of the factors investigated was selected based on previous work (Gerber et al., 2013). Each assay was carried out in duplicate. 
Table 1. Inductors used in the production of lipase from Aspergillus niger using cassava peel as substrate.

\begin{tabular}{cc}
\hline Experiment & Inductors $(\%, \mathrm{~m} / \mathrm{m})$ \\
\hline $\mathrm{SO}$ & Soybean oil $(2.5 \%)$ \\
$\mathrm{MO}$ & Maize oil $(2.5 \%)$ \\
$\mathrm{FO}$ & Frying oil $(2.5 \%)$ \\
$\mathrm{SF}$ & Swine fat $(2.5 \%)$ \\
$\mathrm{SO}+\mathrm{G}$ & Soybean oil $(2.5 \%)+$ Glucose $(1 \%)$ \\
$\mathrm{MO}+\mathrm{G}$ & Maize oil $(2.5 \%)+$ Glucose $(1 \%)$ \\
$\mathrm{FO}+\mathrm{G}$ & Frying oil $(2.5 \%)+$ Glucose $(1 \%)$ \\
$\mathrm{SF}+\mathrm{G}$ & Swine fat $(2.5 \%)+$ Glucose $(1 \%)$ \\
$\mathrm{SO}+\mathrm{G}+\mathrm{YE}$ & Soybean oil $(2.5 \%)+$ Glucose $(1 \%)+$ Yeast extract $(1 \%)$ \\
$\mathrm{MO}+\mathrm{G}+\mathrm{YE}$ & Maize oil $(2.5 \%)+$ Glucose $(1 \%)+$ Yeast extract $(1 \%)$ \\
$\mathrm{FO}+\mathrm{G}+\mathrm{YE}$ & Frying oil $(2.5 \%)+$ Glucose $(1 \%)+$ Yeast extract $(1 \%)$ \\
$\mathrm{SF}+\mathrm{G}+\mathrm{YE}$ & Swine fat $(2.5 \%)+$ Glucose $(1 \%)+$ Yeast extract $(1 \%)$ \\
\hline
\end{tabular}

\subsection{Extraction and determination of lipase activity}

The fermented medium was weighed, added to $45 \mathrm{~mL}$ of 0.1 mol.L-1 sodium phosphate buffer at $\mathrm{pH} 7.0$ and incubated at $35^{\circ} \mathrm{C}$ and $200 \mathrm{rpm}$ for 30 minutes for enzyme extraction. Following extraction, the liquid fraction was separated by filtration and assayed for lipase activities.

Lipase activity was determined by titration method. An emulsion of olive oil (10\% w/v) and arabic gum (5\% w/v) in sodium phosphate buffer 0.1mol.L-1, pH 7.0 was incubated with a sample of the enzymatic extract at $37^{\circ} \mathrm{C}$ and $160 \mathrm{rpm}$ for 15 minutes. The reaction was stopped and the fat acids extracted with a solution of acetone and ethanol (1:1). The fatty acids produced were titrated with $\mathrm{NaOH} 0.05$ mol.L-1 (Freire et al., 1997). One unit of lipase activity was defined as the amount of enzyme that produces $1 \mu \mathrm{mol}$ of fatty acids/minutes, under the assay conditions.

\subsection{Statistical analysis}

Data was analyzed using the Statistica ${ }^{\circledR} 10.0$ (Statsoft Inc.). Significant differences $(\mathrm{p}<0.05)$ between means were identified using Tukey test.

\section{Results and discussion}

In physicochemical characterization of cassava peel was obtained as humidity value before drying $72.26 \%$, ash $2.27 \%$, pH 6.0 and $56.5 \%$ starch, proving to be an appropriate substrate for fermentation. The lipase production was possible in this way due to the supplementation of inductors.

\subsection{Supplementation effect of inductors in lipase activity}


Table 2 shows the results of enzyme activity for the experiments with different inductors.

Table 2. Means of results of lipase activity for lipase production using cassava peel and

\begin{tabular}{cc}
\multicolumn{2}{c}{ different inductors. } \\
\hline Experiment & Lipase activity $(\mathrm{U} / \mathrm{g})$ \\
\hline $\mathrm{SO}$ & $26,24^{\mathrm{a}} \pm 6,24$ \\
$\mathrm{MO}$ & $22.16^{\mathrm{a}} \pm 2.59$ \\
$\mathrm{FO}$ & $23.38^{\mathrm{a}} \pm 2.36$ \\
$\mathrm{SF}$ & $70.82^{\mathrm{cd}} \pm 6.07$ \\
$\mathrm{SO}+\mathrm{G}$ & $86.38^{\mathrm{d}} \pm 0.48$ \\
$\mathrm{MO}+\mathrm{G}$ & $74.38^{\mathrm{cd}} \pm 5.38$ \\
$\mathrm{FO}+\mathrm{G}$ & $59.61^{\mathrm{bc}} \pm 7.39$ \\
$\mathrm{SF}+\mathrm{G}$ & $62.54^{\mathrm{bc}} \pm 6.14$ \\
$\mathrm{SO}+\mathrm{G}+\mathrm{YE}$ & $52.62^{\mathrm{b}} \pm 5.52$ \\
$\mathrm{MO}+\mathrm{G}+\mathrm{YE}$ & $59.75^{\mathrm{bc}} \pm 8.50$ \\
$\mathrm{FO}+\mathrm{G}+\mathrm{YE}$ & $61.20^{\mathrm{bc}} \pm 4.96$ \\
$\mathrm{SF}+\mathrm{G}+\mathrm{YE}$ & $60.92^{\mathrm{bc}} \pm 9.88$ \\
\hline
\end{tabular}

Mean lipase activity followed by different letters differ significantly with $95 \%$ confidence $(\mathrm{p}<0.05)$ by Tukey test.

It is found that the highest values of lipase activity were obtained for the experiments with the addition of soybean oil and glucose $(\mathrm{SO}+\mathrm{G})$, with addition of maize oil and glucose $(\mathrm{MO}+\mathrm{G})$ and with addition of swine fat (SF), statistically equal ( $p>0.05$ ) between themselves and different $(\mathrm{p}<0.05)$ from other experiments, by Tukey test.

Colla et al. (2010) who studied the lipase production using soybean and rice husk obtained $22.5 \mathrm{U} / \mathrm{g}$ of lipase activity. Contesini et al. (2009) obtained $33.03 \mathrm{U} / \mathrm{g}$ of lipase activity using wheat bran as substrate. In the two studies cited, the micro-organisms used were Aspergillus.

The experiments with lower values of lipase activity (consequent decreased production of the enzyme) were experiments with the addition of soybean oil (SO), maize oil (MO) and frying oil (FO), statistically equivalent ( $p>0.05$ ), and none of these experiments was supplemented with glucose or yeast extract.

The production of lipase is mostly inducer dependent; in many cases, oils act as good inducers of the enzyme. The requirement of sugar as a carbon source in addition to lipids varies with the microorganism. In general, media supplemented with glucose along with triglycerides stimulate maximum lipase production in the case of fungi (Rigo et al., 2010). The swine fat is rich in palmitic and oleic acids in the approximate ratio of $1: 2$, corresponding to about $75 \%$ of its fatty acids (Silva and Gioielli, 2006).

Ramani et al. (2010) using lipase from Pseudomonas gessardii showed the highest percentage of hydrolysis using as substrate the bovine fat (146\%) followed by goat fat (112\%) and olive oil (100\%). Affirms that the capacity of lipase to hydrolyze all substrates has great potential for application in the hydrolysis of lipids for the treatment of wastewater. 
For the next steps, it was decided to as an inducer the fat swine, for being an economically viable alternative as inductor in relation other inductors that showed similar results statistically.

\subsection{Optimization of lipase production}

Table 3 presents the matrix of the complete factorial design with the lipase activity obtained at 60 hours of fermentation. The highest lipase production, showed higher amount of lipase activity occurred to the experiment E3, with mean $72.26 \mathrm{U} / \mathrm{g}$ lipase activity of, with a temperature of $36^{\circ} \mathrm{C}$ and the percentage of inductor $1.0(\mathrm{w} / \mathrm{w})$. By Tukey test can verify that the result of the experiment E3 differs significantly $(p<0.05)$ for all other experiments.

Table 3. Matrix of the experimental design (real and coded values) with responses in terms of lipase activity for lipase production using swine fat as inductor.

\begin{tabular}{cccc}
\hline Experiment & Temperature $\left({ }^{\circ} \mathrm{C}\right)$ & Inductor concentration $(\%, \mathrm{~m} / \mathrm{m})$ & Lipase activity $(\mathrm{U} / \mathrm{g})^{*}$ \\
\hline E1 & $25(-1)$ & $1.0(-1)$ & $18.15^{\mathrm{b}} \pm 0.21$ \\
E2 & $25(-1)$ & $4.0(+1)$ & $34.22^{\mathrm{c}} \pm 1.67$ \\
E3 & $36(+1)$ & $1.0(-1)$ & $72.26^{\mathrm{g}} \pm 2.55$ \\
E4 & $36(+1)$ & $4.0(+1)$ & $67.56^{\mathrm{f}} \pm 3.35$ \\
E5 & $22.7(-1.41)$ & $2.5(0)$ & $10.93^{\mathrm{a}} \pm 3.03$ \\
E6 & $38.2(+1.41)$ & $2.5(0)$ & $52.63^{\mathrm{e}} \pm 6.56$ \\
E7 & $30.5(0)$ & $0.4(-1.41)$ & $43.99^{\mathrm{d}} \pm 0.66$ \\
E8 & $30.5(0)$ & $4.6(+1.41)$ & $47.03^{\mathrm{d}} \pm 0.46$ \\
E9 (C) & $30.5(0)$ & $2.5(0)$ & $48.33^{\mathrm{d}} \pm 1.13$ \\
E10 (C) & $30.5(0)$ & $2.5(0)$ & $50.46^{\mathrm{de}} \pm 2.64$ \\
\hline
\end{tabular}

Mean lipase activity followed by different letters differ significantly with $95 \%$ confidence $(\mathrm{p}<0.05)$ by Tukey test. $*$ Lipase activity \pm Standard deviation $( \pm)$

The enzyme productivity was also determined in 60 hours of fermentation being achieved $1.20 \mathrm{U} / \mathrm{g} . \mathrm{h}$ (experiment E3). This value is higher that obtained by Kempka et al. (2008), 0.99 U/g.h in 60 hours of fermentation using Aspergillus niger, by Gerber et al. (2013), 0.74 U/g.h in 72 hours of fermentation using Penicillium verrucosum, by Gutarra et al. (2005), 0.26 U/g.h in 72 hours of fermentation and by Mahadik et al. (2002), 0.87 U/g.h in 144 hours of fermentation using Aspergillus niger and wheat bran/sunflower oil as substrate.

Biological processes are highly complex and the enzyme production depends on the interaction of several processes influencing microbial cellular metabolism (Gerber et al., 2013). Figure 1 shows a Pareto Diagram obtained from experimental results of the lipase activity. 


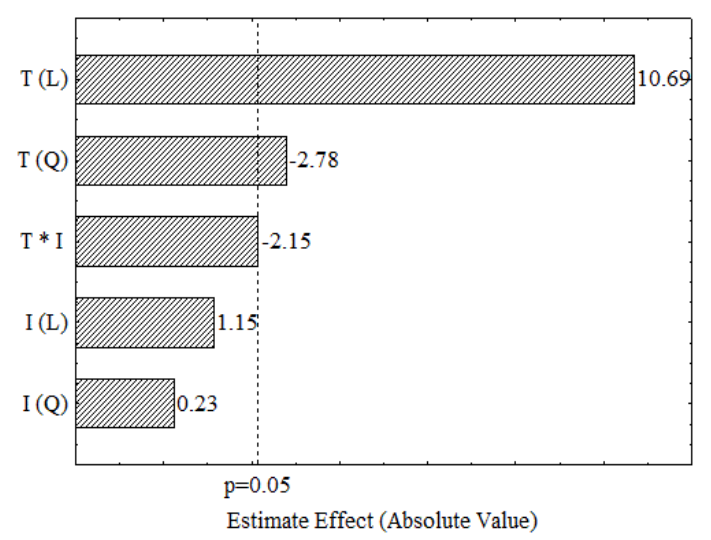

Figure 1. Pareto chart obtained from experimental results of the lipase activity using cassava peel as substrate and swine fat as inductor.

$$
\begin{aligned}
& L A=296.08+17.62 * T-0.21 * T^{2} \\
& -0.63 * T * I
\end{aligned}
$$

where LA denotes lipase activity (U/g dry substrate), $\mathrm{T}$ is the temperature and I the inductor concentration.

The model generated a response surface for lipase activity (R2=0.904), shown in Figure 2. This surface indicates that the conditions that maximize lipase activity production are $36^{\circ} \mathrm{C}$, any of inductor concentration (swine fat) within the range tested.

The experiments where there was a higher lipase activity were $\mathrm{E} 3\left(36^{\circ} \mathrm{C}\right.$ and $1 \%$ of swine fat), $\mathrm{E} 4\left(36^{\circ} \mathrm{C}\right.$ and $4.0 \%$ of swine fat) and $\mathrm{E} 6\left(38.2^{\circ} \mathrm{C}\right.$ and $2.5 \%$ of swine fat). Therefore, the condition that presents the greatest advantage is the corresponding experiment E3, that among the listed above, has the lowest temperature and lower concentration of inductor.

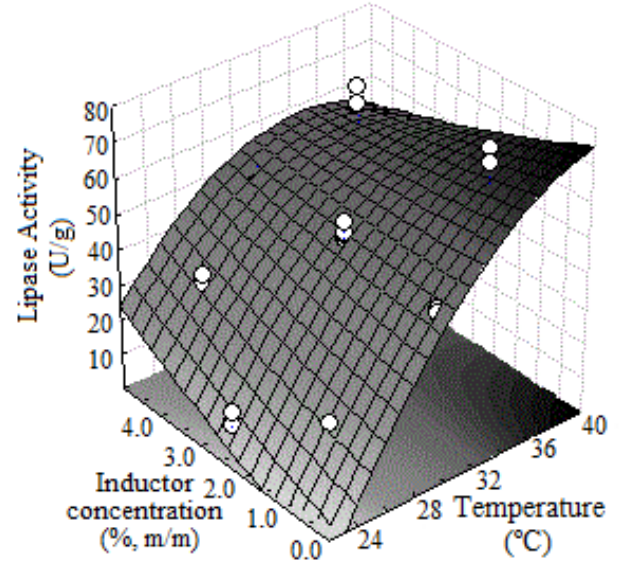

Figure 2. Response surface for lipase activity as a function of inductor concentration and temperature. 


\section{Conclusions}

The fungus Aspergillus niger showed a good performance in the enzyme production. The best inductor for the lipase production was swine fat which provided a lipase activity of 70.82 $\mathrm{U} / \mathrm{g}\left(\mathrm{T}=27.5^{\circ} \mathrm{C}, 2.5 \% \mathrm{w} / \mathrm{w}\right.$ of an inductor). In relation the variables for optimization of lipase production using fat swine as inductor (the inductor temperature and percentage), the temperature had a positive significant effect on lipase activity. The temperature of $36^{\circ} \mathrm{C}$ and a concentration of $1 \%(\mathrm{w} / \mathrm{w}$ ) fat swine led to the maximum lipase activity, as a value of $72.26 \mathrm{U} / \mathrm{g}$. More studies are needed to complement the present study.

\section{References}

COLLA, L. M., RIZZARDI, J., PINTO, M. H., REINEHR, C. O., BERTOLIN, T. E., COSTA J. A. V. 2010. Simultaneous production of lipases and biosurfactants by submerged and solid-state bioprocesses. Bioresource Technology, 101, 8308-8314,

CONTESINI, F. J., LOPES, D. B., MACEDO, G. A., NASCIMENTO, M. G., CARVALHO, P. O. 2010. Aspergillus sp. lipase: Potential biocatalyst for industrial use. Journal of Molecular Catalysis B: Enzymatic. 67, 163-171.

CONTESINI, F. J., SILVA, V. C. F., MACIEL, R. F., LIMA, R. J., BARROS F. F. C., CARVALHO, P. O. 2009. Response surface analysis for the production of an enantioselective lipase from Aspergillus niger by solid-state fermentation. The Journal of Microbiology.47, 563571.

DAMODARAN, S., PARKIN, K., FENNEMA, O. R. 2010. Química de Alimentos de Fennema, Artmed, 900p.

FREIRE, D. M. G., TELES, E. M. F., BON, E. P. S., SANT’ANNA, JR. G. L. 1997. Lipase production by Penicillium restrictum in a laboratory scale fermentor: media composition, agitation and aeration. Biotechnology and Applied Biochemistry, 63, 409-421.

GERBER, C. B., KAUFMANN, F., NICOLETTI, G., COSTA, M. D., KEMPKA, A. P. 2013. Production of lipase using cassava peel and sunflower oil in solid-state fermentation: preliminary study. Journal of Agricultural Science and Technology A, 3, 948-954.

GUNCHEVA, M., ZHIRYAKOVA, D. 2011. Catalytic properties and potential applications of Bacillus lipases. Journal of Molecular Catalysis B: Enzymatic. 68, 1-21.

GUPTA, R., GUPTA, N., RATHI, P. 2004. Bacterial lipases: an overview of production, purification and biochemical properties. Applied Microbiology and Biotechnology. 64, 763-781. GUTARRA, M. L. E., CASTILHO, L.R., FREIRE, D. M. G., SANTANNA, JR. G.L. 2005. Lipase production by solid-state fermentation: cultivation conditions and operation of tray and packed-bed bioreactors. Applied Biochemistry and Biotechnology. 121, 105-116.

HASAN, F., SHAH, A. A., HAMEED, A. 2006. Industrial applications of microbial lipases. Enzyme and Microbial Technology, v.39, p.235-251, 2006.

INSTITUTO ADOLFO LUTZ. 2008. Métodos químicos e físicos para análise de alimentos. 4.ed. São Paulo: IMESP, 1020p.

KEMPKA, A. P., LIPKE, N. L., PINHEIRO, T. L. F., MENONCIN, S., TREICHEL, H., FREIRE, D.M.G., DI LUCCIO, M., OLIVEIRA, D. 2008. Response surface method to optimize the production and characterization of lipase from Penicillium verrucosum in solid-state fermentation. Bioprocess Biosystem Engineering. 31, 119-125.

KOBLITZ M. G. B. 2008. Bioquímica de Alimentos: Teoria e Aplicações Práticas. Rio de Janeiro. Editora Guanabara Koogan. 
LI, N., ZONG, M-H. 2010. Lipases from the genus Penicillium: production, purification, characterization and applications. Journal of Molecular Catalysis B: Enzymatic. 66, 43-54.

MAHADIK, N. D., PUNTAMBEKAR, U. S., BASTAWDE, K. B., KHIRE, J. M., GOKHALE, D. V. 2002. Production of acidic lipase by Aspergillus niger in solid state fermentation. Process Biochemistry. 38, 715-721.

NELSON D. L., COX M. M. 2011. Princípios de Bioquímica de Lehninger. Editora Artmed S.A., $1274 \mathrm{p}$.

RAMANI, K., KENNEDY, L. J., RAMAKRISHNAN, M., SEKARAN, G. 2010. Purification, characterization and application of acidic lipase from Pseudomonas gessardii using beef tallow as a substrate for fats and oil hydrolysis. Process Biochemistry, 45, 1683-1691.

RIGO E., NINOW J. L., DI LUCCIO M., OLIVEIRA J. V., POLLONI A. E., REMONATTO D., ARBTER F., VARDANEGA R., OLIVEIRA D., TREICHEL H. 2010. Lipase production by solid fermentation of soybean meal with different supplements. LWT-Food Science and Technology. 43, 1132-1137.

SALIHU, A., ALAM, M. Z., ABDULKARIM, M. I., SALLEH, H. M. 2011. Effect of process parameters on lipase production by Candida cylindracea in stirred tank bioreactor using renewable palm oil mill effluent based medium. Journal of Molecular Catalysis B: Enzymatic. 72, 187- 192.

SALIHU, A., ALAM, M. Z., ABDULKARIM, M. I., SALLEH, H. M. 2012. Lipase production: An insight in the utilization of renewable agricultural residues. Resources, Conservation and Recycling. 58, 36-44.

SANTIS-NAVARRO, A., GEA, T., BARRENA, R., SÁNCHEZ, A. 2011. Production of lipases by solid state fermentation using vegetable oil-refining wastes. Bioresource Technology.102, 10080-10084.

SILVA, R. C, GIOIELLI, L. A. 2006. Propriedades físicas de lipídios estruturados obtidos a partir de banha e óleo de soja. Brazilian Journal of Pharmaceutical Sciences. 42, 223-235.

TAN, T., ZHANG, M., WANG, B., YING, C., DENG, L. 2003. Screening of high lipase producing Candida sp. and production of lipase by fermentation. Process Biochemistry. 39, 459465 . 